\title{
Correction to: Own and other person's transgressions: guilt as a function of self-construal
}

\author{
Roland Neumann ${ }^{1}$ iD \\ (C) The Author(s) 2021
}

\section{Correction to: Current Psychology. https://doi.org/10.1007/s12144-020-01079-3}

The article "Own and other person's transgressions: Guilt as a function of self-construal", written by Roland Neumann, was originally published electronically on the publisher's internet portal on 21 September 2020 without open access. With the author(s)' decision to opt for Open Choice the copyright of the article changed on 02 June 2021 to (C) The Author(s) 2021 and the article is forthwith distributed under a Creative Commons Attribution 4.0 International License, which permits use, sharing, adaptation, distribution and reproduction in any medium or format, as long as you give appropriate credit to the original author(s) and the source, provide a link to the Creative Commons licence, and indicate if changes were made. The images or other third party material in this article are included in the article's Creative Commons licence, unless indicated otherwise in a credit line to the material. If material is not included in the article's Creative Commons licence and your intended use is not permitted by statutory regulation or exceeds the permitted use, you will need to obtain permission directly from the copyright holder. To view a copy of this licence, visit http://creativecommons.org/ licenses/by/4.0. Open access funding enabled and organized by Projekt DEAL.

The original article has been corrected.

Publisher's Note Springer Nature remains neutral with regard to jurisdictional claims in published maps and institutional affiliations.

The online version of the original article can be found at https://doi.org/ 10.1007/s12144-020-01079-3

Roland Neumann

neumannr@uni-trier.de

1 Department of Psychology, University of Trier, Trier, Germany 